\title{
Examining the Relationship between Translation Students' Locus of Control and Their Translation Achievement
}

\author{
Behzad Ghonsooly \\ Department of English Language and Literature, Ferdowsi University of Mashhad, Iran \\ E-mail: Ghonsooly@um.ac.ir
}

Ali Moharer (Corresponding author)

Department of English Language and Literature, Ferdowsi University of Mashhad, Iran E-mail: Ali.Moharer@gmail.com

Received: March 21, 2012 Accepted: April 2, 2012 Published: June 1, 2012

doi:10.5296/ijl.v4i2.1796

URL: http://dx.doi.org/10.5296/ijl.v4i2.1796

\begin{abstract}
This paper investigates the effect of Locus of Control (LOC) on translation students' achievement. Participants of the study included 151 BA seniors who studied English Translation at Mashhad Universities and Institutes of higher education. Both male and female students filled in the LOC questionnaire.The Persian version of LOC (Ghonsooly \& Elahi, 2010) was used to measure the participants' Locus of Control. The results of the statistical analyses revealed that students' Locus of Control has a significant and positive relationship with their translation achievement. The results of the interview phase of the study were also consistent with the statistical analyses.
\end{abstract}

Keywords: Locus of control, Translation achievement 


\section{Introduction}

Dornyei argues that Individual Differences are the peculiarities which vary from one individual to another (2005). Locus of Control which was presented by Rotter in 1966 is a psychological factor that causes differences in the performance of students.

Despite the heavy load of research done on different realms of translation studies, especially translation strategies (e.g., Krings, 1986; Koster, 2002; Molina \& Amparo, 2002; Hatim and Munday, 2004; Chesterman, 2005) lack of the relationship of some psychological factors such as LOC with translation achievement of university students is obvious. This study was designed to address the following research questions:

1) Is there any relationship between translation students' Locus of Control and their translation achievement?

2) Is there any significant difference in the translation achievement of students with higher levels of Locus of Control and those with lower levels of Locus of Control?

\section{Review of Literature}

\subsection{Locus of Control}

'Locus of control theory' or 'general expectancies' was developed by Rotter in 1966. According to this theory students perform tasks differently due to their beliefs about their achieving their expected goals or purposes. According to Rotter (1966) locus of control orientation depends on various factors which include environmental, cultural or personal variables. Internalizers attribute success or failure to their efforts and abilities while externalizers believe their succes and failure are related to circumstances which are beyond personal control. According to Rotter (1982) external factors may include fate, luck, the will of other people or some other external forces such as God or nature.

\subsubsection{Loc and Achievement}

Social behaviors and psychological states of the individuals have been studied frequently concerning an individual's beliefs about locus of control. Achievement-related activities seem to be one set of social behaviors that have been studied vastly. There seems to be a logical relationship between LOC beliefs and what an individual achieves. According to Phares (1976) people who are capable of controlling the results should work harder if they want to be more successful. In addition, internalizers and externalizers' reaction toward success and failure is different. So, it means that when the result is satisfactory, internalizers feel pride but when the result is not as it was expected to be, they feel shame and experience less intense feelings.

Some studies have associated internal LOC beliefs with behaviors that influence the success achievement among which Ducette and Wolk (1972) investigated that externalizers show less persistence at tasks. A positive relationship has been found between internality and the tendency to procrastinate rewards so as to increase them (e.g., Bialer, 1961; cited in Findley and Cooper, 1983) and also between internality and preference to act in skill rather than in chance situations (e.g., 
Rotter \& Mulry, 1965; cited in Findley and Cooper, 1983). Each tendency should mean internalizers are more likely to be successful.

What has attracted the researches' attention is how internality can affect achievement. This has led them to conduct some research projects to come to valuable conclusions. In one of this related studies, Phares (1976) has examined the relation between LOC and achievement among children. He used the Intellectual Achievement Responsibility (IAR) Scale (Crandall, Katkovsky, \& Crandall, 1965; cited in Phares, 1976) as LOC measure and grades or standardized test scores as indexes of academic achievement in most of his studies. Phares (1976) came to the conclusion that internalizers were more successfull than externalizers and had a better performance.

Students who relate their success to internal factors expect future successes and students who relate failure to internal factors may expect future failure unless they assume themselves capable of and actively address those factors. On the contrary, relating success to external factors would make future successes unpredictable. Internal LOC seems to be a positive predictor of academic achievement and external LOC to be a negative predictor of academic achievement (Eachus, P. \& Cassidy, S. 1997).

Another research was done by Park and Kim in 1998. The study compared university top students who had got scholarships with those students who were not much successful. Then they analyzed the students' behavior patterns and their locus of control. The results revealed that top students showed higher internalized LOC and lower externalized locus of control.

\section{Methodology}

\subsection{Participants}

In this study a total number of 151 students of English translation were chosen in order to fill in the LOC questionnaire. All of them were senior students of translation who had passed two basic courses, namely "Principles and Methodology of Translation" and "Theories of Translation". The participants were both male and female students. They were selected from Ferdowsi university of Mashhad, Khayam, and Tabaran Institutes of Higher Education.

\subsection{Instrumentations}

\subsubsection{The LOC instrument}

In 1984 Duttweiler designed a questionnaire to measure where a person tries to find or is able to get reinforcement. This questionnaire included twenty eight items and was called 'Internal Locus of Control Index' (ICI). In this study the Persian translation of Internal Control Index questionnaire (Ghonsooly \& Elahi, 2010) is used to measure the participants' LOC. In this scale each item is scored on a 5-point Likert scale from A (rarely) to E (usually). Half of the items are worded so that high internally oriented respondents are expected to answer half at the 'usually' end of the scale and the other half at the 'rarely' end of the scale. The 'rarely' 


\section{Macrothink}

International Journal of Linguistics

ISSN 1948-5425

2012, Vol. 4, No. 2

response is scored as 5 points on items 1, 2, 4, 6, 11, 14, 17, 19, 22, 23, 24, 26, and 27; for the remainder of the items, the response 'usually' is scored as 5 points.

\subsubsection{The Achievement Instrument}

The participants' Grand Point Averages (GPA) of their translation course exams also served to measure their translation achievement.

\subsection{Data Collection}

In the first step, after obtaining permission from the instructors, the second researcher visited the translation classes to administer the LOC questionnaires. Students were assured that the results would be confidential and their instructors would not see the results of the questionnaires. The students were introduced to the LOC questionnaire. Then, they rated the items of questionnaire on a 5 point Likert scale with responses of rarely, occasionally, sometimes, frequently, and usually. While they were filling in the questionnairs, they were served with sweet and juice for a better concentration. They were also asked to write it down in the sheet whether they would like to participate in the interview or not.

\subsection{Data Analysis}

In order to answer the first research question the Spearman correlation formula was used. Also, to answer the second research question an independent samples t-test was used. The mean score of the translated version of Internal Locus of Control Index (ICI) was used as the cut-off score between internalizers and externalizers.

\section{Results}

The first research question deals with the relationship between translation students' LOC and their translation achievement. The Spearman formula was used to examine such a relationship (see Table 1).

Table 1. Correlation between LOC and Translation Achievement 


\begin{tabular}{|c|c|c|c|c|}
\hline \multicolumn{5}{|c|}{ Correlations } \\
\hline & & & LOC & $\begin{array}{l}\text { Translation } \\
\text { Achievement }\end{array}$ \\
\hline \multirow{6}{*}{$\begin{array}{l}\text { Spearman's } \\
\text { rho }\end{array}$} & \multirow{3}{*}{ Loc } & $\begin{array}{l}\text { Correlation } \\
\text { Coefficient }\end{array}$ & 1.000 & .68 \\
\hline & & Sig. (2-tailed) & .000 & .000 \\
\hline & & $\mathrm{N}$ & 151 & 151 \\
\hline & \multirow{3}{*}{$\begin{array}{l}\text { Translation } \\
\text { Achievement }\end{array}$} & $\begin{array}{l}\text { Correlation } \\
\text { Coefficient }\end{array}$ & .68 & 1.000 \\
\hline & & Sig. (2-tailed) & .000 & .000 \\
\hline & & $\mathrm{N}$ & 151 & 151 \\
\hline
\end{tabular}

As can be seenin Table 1, the correlation coefficient for the two variables in question turned out to be 0.68 which is significant at $\mathrm{P}<0.05$. This correlation is significantly high and positive. Therefore, it can be concluded that the higher translation students' LOC is, the better their translation achievement is.

An independent samples t-test was used to see whether there is a difference between internalizers and externalizers concerning their translation achievement (see Table 2).

Table 2. Descriptive Statistics: Translation Achievement vs. High and Low LOC

\begin{tabular}{|l|l|l|l|}
\hline \multicolumn{3}{|l|}{ Group Statistics } \\
\hline Mean & N & LOC & \\
\hline 13.8262 & 73 & Lower & \\
\hline 17.5469 & 78 & Higher & GPA \\
\hline
\end{tabular}


As illustrated in Table 2, the mean score of translation students with high LOC is 17.5 and that of those with lower LOC is 13.8. Table 3 demonstrates whether this difference in mean scores is significant or not.

Table 3. Independent Samples t-Test: LOC \& Achievement

\begin{tabular}{|l|l|l|}
\hline \multicolumn{2}{|l|}{ Independent Samples Test } \\
\hline Sig. & Df & T \\
\hline .000 & 149 & 1.98 \\
\hline
\end{tabular}

Table 3 shows that the difference between the two mean scores is significant, $t(149)=1.98$, $\mathrm{p}<.05$, and translation students with high LOC have higher achievement scores than those with low LOC.

\section{Discussion}

The findings of the current study indicated that internalizers are superior to externalizes with regard to translation achiechvement. In other words, translatation students with internal locus of control tend to be more successful in their translation tasks. Unfortunately, there has been a dearth of research on translation achievement. Hence, it is fairly difficult to compare this finding with the related literature. However, we can consider translation achievement as a construct that is similar to academic achievement in general. The most important reason for this juxtaposition, i.e. translation achievement with academic achievement, is possibly that they are both defined in terms of success in exams. Therefore, the researchers tried to justify the robust association between LOC and translation achievement found in this study in light of the contribution of LOC to academic achivement in general.

The strong link between LOC and academic achievement in general, and translation achievement in particular, is in agreement with Galjas and D'Silva (1981), Gifford, Mianzo, and Briceno-Perriott (2006), Wood, Saylor, Cohen (2009), Hadsell (2009), Ghonsooly and Elahi (2010), Hosseini and Elahi (2010), and Ghapanchi and Golparvar (2011). Ducette and Wolk (1972) concluded that those with internal locus of control show more persistence (cited in Ghapanchi and Golparvar, 2011). Morris and Messer (1978) also found that internalizers have more academic task persistence. Consequently, translation students who are internally oriented are more persistent in their translation tasks. Kernis (1984) similarly found that individuals, who are internally controlled, are more task oriented. This may explain the fact that students with internal locus of control devote more effort to and spend more time on their academic tasks that leads to more academic success. Interestingly, this assumption is reflected in the data gathered through interviews. Translation students with internal locus of control hold 
the belief that they have control over what happens to them. On the other hand, translation students who are externalizers, ascribe their success or failure to external factors like task difficulty or luck. Basgall and Snyder (1988) contended that these students hold that there is no use in trying because their efforts are futile and they are doomed to failure. Thus, they are not motivated to work hard to become successful in their translation tasks and tests. In a similar vein, frequent use of external attributions makes them lose their motivation to progress (Basgall \& Snyder, 1988). While, internalizers believe that they can control their translation process, so they have more motivation to cope with the problems they face in the process of their translation (Dornyei, 2005). Since internalizers believe they can control their learning, they take the responsibility of their learning, and this makes them more motivated to work hard which leads to further success in translation.

Since LOC is an approach to motivation (Dornyei, 2005), it is postulated that translation students with higher LOC are more motivated than those with lower LOC. Therefore, the better achievement supported by the findings of the present study can originate from the higher levels of internalizes' motivation than externalizers.

Such inference was also supported by the findings of the interviews. The internalizers mentioned that they we really encouraged to do translation tasks. It was interesting that both groups of internalizers and externalizers were motivated before doing translation tasks but only internalizers could maintain their motivation until the end of the tasks. This observed fact can be supported by William and Burdens' (1997) theory of motivation.

Williams and Burden (1997) found it really useful to distinguish three stages of motivation. They maintained that these three stages include a mixture of internal and external influences which may be personal to different learners, who may make sense of a variety of events happening around them. Second, they considered what is actually involved in doing something such as what motivates individuals to carry out a particular task. For example, a learner may have strong reasons for doing something, but not any especial decisions to put them into practice. Finally, individuals need to sustain the effort necessary to finish the activity to their own satisfaction. In other terms, motivation is beyond just arousing interest. It also includes sustaining the aroused interest and spending time and energy to regulate the necessary effort to gain certain goals.

Based on this theory, it can be inferred that internalizers are higher achievers in translation achievement because they have motivation on their side. They are highly motivated to persist in coping with the possible problems and take the responsibility of their success in translation achievement by spending more time, energy, and effort. The interactions of these three stages of Williams and Burdens' motivational model can indicate well how the internal influences to which internalizers attribute their achievement and failure motivate them directly to make all their efforts to gain their desirable results. 


\section{Conclusion}

In general, translation instructors who are familiar with the concept of LOC seem to be more successful in helping students take control of their translation process and assist them how to plan, evaluate, and monitor their translation. Therefore, through mediation, mismatches in the LOC scope can be mainly reduced.

\section{References}

Basgall, J. A., \& Snyder, C. R. (1988). Excuses in waiting: External locus of control and reactions to success-failure feedback. Journal of Personality and Social Psychology, 54, 656662. http://dx.doi.org/10.1037/0022-3514.54.4.656

Chesterman, A. (2005). Problems with strategies, in K. Károly \&\& Á. Fóris (Eds) New trends in translation studies: In honor of Kinga Klaudy (17-28). Budapest: Akadémiai Kiadó.

Dornyei, Z. (2005). The psychology of the language learner: Individual differences in second language acquisiton. Mahwah, N.J.: Lawrence Earlbaum.

Dornyei, Z. (2005). The psychology of language learner: Individual differences in second language acquisition. New Jercy: Lawrence Erlbaum Associates.

Ducette, J., \& Wolk, S. (1972). Locus of control and extreme behavior. Journal of Consulting and Clinical Psychology, 39, 253-258.

Duttweiler, P. C. (1984). The internal control index: A newly developed measure of locus of control. Education and Psychological Measurement, 44, 209-221. http://dx.doi.org/10.1177/0013164484442004

Eachus, P. \& Cassidy, S. (1997). Self-efficacy, locus of control and styles of learning as contributing factors in the academic performance of student health professionals. Proceedings of the First Regional Congress of Psychology for Professionals in the Americas, Mexico City.

Findley, M. J., \& Cooper H. M. (1983). Locus of control and academic achievement: A literature review. Journal of Personality and Social Psychology, 44(2): 419 - 427.

Galjes, I., \& D'Silva, C. (1981). Locus of control and achievement of Nigerian school-age $\begin{array}{lllll}\text { children. } \quad \text { Journal } & \text { Psychology, } & 109, & \end{array}$ http://dx.doi.org/10.1080/00223980.1981.9915306

Ghonsooly, B., \& Elahi, M. (2010). Validating locus of control questionnaire and examining its relation to General English achievement. Journal of Teaching Language Skills, 2(1), 117-143.

Ghapanchi, Z., \& Golparvar, S. E. (2011). On the relationship between locus of control and Iranian students' English score in the university entrance exam. International Journal of Linguistics, 3(1), 1-19. 
Gifford, D., Mianzo, F., \& Briceno-Perriott, J. (2006). Locus of control, academic achievement, and retention in a sample of university first-year students. Journal of College Admission, 18-25.

Hadsell, L. (2009). Achievement goals, locus of control, and academic success and effort in introductory and intermediate microeconomics. Paper to be presented at the ASSA Annual Meetings Session sponsored by the AEA Committee on Economic Education Atlanta, GA.

Hatim, B., \& Munday, J. (2004). Translation: An advanced resource book. New York \& London: Routledge.

Hosseini Fatemi, A., \& Elahi, M. (2011). On the alleged relationship between Locus of control, L2 reading achievement and use of language learning strategies. Ferdowsi Review, 1, $21-47$.

Kernis, M. A. (1984). Internal versus external attributions are important determinants of subsequent performance. (ERIC Document Reproduction Service No. ED 195 326).

Krings, H. P. (1986). Translation problems and translation strategies of advanced German learners of French. In J. House, \& S. Blum-Kulka (Eds.), Interlingual and intercultural communication (pp. 263-75). Tubingen: Gunter Narr.

Koster, C. (2002). The translator between texts: On the textual presence of the translator as an issue in the methodology of comparative translation description. In A. Riccardi (ed.) Translation studies: Perspectives on an emerging discipline (24-37), Cambridge: Cambridge University Press.

Molina, L., \& Amparo H. A. (2002). Translation techniques revisited: A dynamic and functionalist approach. Meta, 47(4), 498-512.

Morris, S., \& Messer, S. (1978). The effect of locus of control and locus of reinforcement on motivation in the work performance of black managers. Journal of Industrial National Middle School Association.

Park, Y. S., \& Kim, U. (1998). Locus of control attribution style, and academic achievement comparative analysis of Korean, Korean-Chinese, and Chinese students. Asian Journal of Social Psychology, 4, 191-208. http://dx.doi.org/10.1111/1467-839X.00013

Phares, E. J. (1976). Locus of control in personality. Morristown, N.J: General Learning Press.

Rotter, J. B. (1966). Internal - external locus of control scale (I.E.). Assess locus of control dimension of personality: Internal or external.

Rotter, J. B. (1982). The development and application of social learning theory: Selected papers. New York: Praeger. 


\section{Macrothink}

International Journal of Linguistics

ISSN 1948-5425

2012, Vol. 4, No. 2

Williams, M., \& Burden, R. (1997). Psychology for language teachers . Cambridge: Cambridge University Press.

Wood, A. M., Saylor, C., \& Cohen, J. (2009). Locus of control and academic success among ethnically diverse Baccalaureate nursing students. Nursing Education Perspectives, 30(5), 290-294.

\section{Appendix}

Appendix 1. English Version of the Internal Control Index (ICI)

Please read each statement. Where there is a blank, decide what your normal or usual attitude, feeling, or behavior would be:

$\mathrm{A}=$ Rarely (less than $10 \%$ ) of the time)

$\mathrm{B}=$ Occasionally (about $30 \%$ of the time)

$\mathrm{C}=$ Sometimes (about half the time)

$\mathrm{D}=$ Frequently (about $70 \%$ of the time)

$\mathrm{E}=$ Usually (more than $90 \%$ of the time)

Of course, there are always unusual situations, in which this would not be the case, but think of what you would do or feel in most normal situations.

Write the letter that describes your usual attitude or behavior in the space provided on the response sheet.

1. When faced with a problem I try to forget.

2. I need frequent encouragement from others for me to keep working at a difficult task.

3. I like jobs where I can make decisions and be responsible for my own work.

4. I change my opinion when someone I admire disagrees with me.

5. If I want something I work hard to get it.

6. I___ prefer to learn the facts about something from someone else rather than having to dig them out for myself.

7. I will accept jobs that require me to supervise others.

8. I have a hard time saying "no" when someone tries to sell me something.

9. I like to have a say in any decisions made by any group I'm in.

10. I consider the different sides of an issue before making any decisions.

11. What other people think has a great influence on my behavior. 
12. Whenever something good happens to me I feel it is because I've earned it.

13. I enjoy being in a position of leadership.

14. I need someone else to praise my work before I am satisfied with what I've done.

15. I am sure enough of my opinions to try and influence others.

16. When something is going to affect me I learn as much about it as I can.

17. I decide to do things on the spur of the moment.

18. For me, knowing I've done something well is more important than being praised by some else.

19. I let other peoples' demands keep me from doing things I want to do.

20. I stick to my opinions when someone disagrees with me.

21. I do what I feel like doing not what other people think I ought to do.

22. I get discouraged when doing something that takes a long time to achieve results.

23. When part of a group I prefer to let other people make all the decisions.

24. When I have a problem I follow the advice of friends or relatives.

25. I enjoy trying to do difficult tasks more than I enjoy trying to do easy tasks.

26. I prefer situations where I can depend on someone else's ability rather than just my own.

27. Having someone important tell me I did a good job is more important to me than feeling I've done a good job.

28. When I'm involved in something I try to find out all I can about what is going on even when someone else is in charge. 
Appendix 2.The Persian Translation of Locus of Control Index

$$
\text { ترم و نام درس: }
$$

هر يك از جملات زير را بخوانيل و جاهاى خالى را با توجه به نكرش، احساس و رفتار خود بر نماييد.

$$
\begin{aligned}
& \text { الفــ به ندرت ( كمتر از 10\% مو اقع ) } \\
& \text { بـ كهخاه (حدود } 30 \text { \% مو اقع ) } \\
& \text { ج- كَاهى اوقات (حدود } 50 \text { \% مواقع) } \\
& \text { د- مكرراً (حدود } 70 \text { \% مو اقع) } \\
& \text { هـ معدو لا (بيش از } 90 \text { \% مو اقع) }
\end{aligned}
$$

حرف مريوط به كزينهاى كه نكرش يا رفتار معمول شما را توصيف مىكند در جاى خالى قرار دهيد.

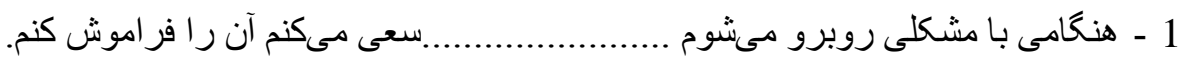

بابه تشويق مكرر ديكران نياز دارم.

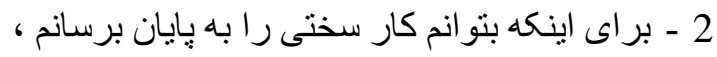

شغلهايى را دوست دارم كه تصميمكيرى و مسئوليت آن بر عهده خودم باثد. $-3$

نظر خود را تغيير. 4 - وقتى كسى كه مورد تحسين من است با نظر من مخالفت مى كند،

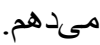

$$
5 \text { - اكر جيزى ر ا بخو اهم ........................ بر ائ بذت آوردنش سخت تلاش مىكن. }
$$

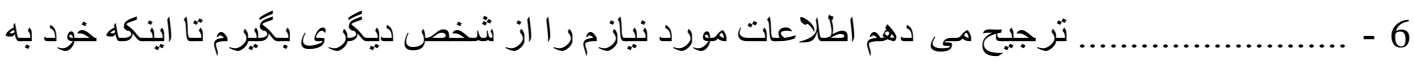

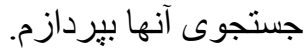

شغلهايى را قبول مى كنم كه ناظر ديكران باشم. - 7

8 - . . .........................

دوست دارم در مورد هر تصميمى كه كرو هم مىكيرد حق اظهار نظر داشته باثم.

جو انب مختلف آن را در نظر مىكيرم. 10 ـهنحاميكه مىخو اهم تصميمى بكيرم

$$
\text { تأثنير زيادى در رفتار من دارد. }
$$
11 آنجه كه ديكران فكر مىكنند

احساس مىكنم كه خود باعث آن شده ام. 12 هـر وقت اتفاق خوشايندى بر ايم مىافتن.

$$
\text { بِّت هاى مديريتى را دوست دارم. }
$$

قبل از اينكه از كار هاى خود احساس رضايت كنم نياز دارم كه ديكر ان تشويقم كنند. 14

آنقدر به نظر ات خود اطمينان دارم كه مى دانم ديكر ان را تحت تاثثر قر ار مى دهم. 15

سعى مى كنم تا جايى كه مىتو انم آن را باد بكيرم. 16 و وقتى از جيزى خوشم مى آيد ...... تصميم مىكيرم كه كار هار ا در لحظه آخر انجام دهم. 
انجام درست كار بر ايم مهمتر از تحسين ديكران است.....

خواستههاى ديكران مرا از كارى كه انجام مىدهم باز مىدارد. 19

وقتى كسى با نظرم مخالفت مىكند روى نظرم بِافشارى مىكنم. 20

كارى را انجام مى دهم كه خودم فكر مى كنم درست است نه آنجه را كه ديكر ان فكر مى كنتد 21

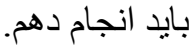

....از انجام كار هايى كه نتيجه آن دير مشخص مىشود مأيوس مىشوم. 22

هنگامى كه عضو كرو هى هستم ، ترجيح مىدهم كه همه تصميم ها را ديكر ان بكيرند. $-23$

به نصيحت دوستان و اقو ام عمل مى كنم.

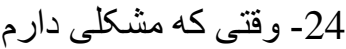

انجام كار هاى سخت بر ايم خوشايندتر از انجام كار هاى ساده است. $-25$

موقعيت هايى را ترجيح مى دهم كه بيش از نو انايى هاى خود به نو انايى هاى ديكر ان اتكا $-26$ كن.

27- اكر كسى به من بكويد كه كارم را خوب انجام داده ام، بر ايم مهمتر مهمتر است از اينكه خودم احساس كنم

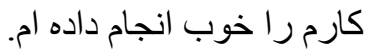

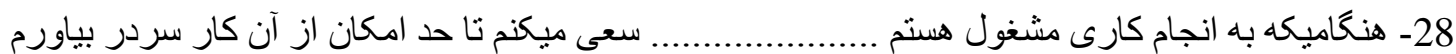

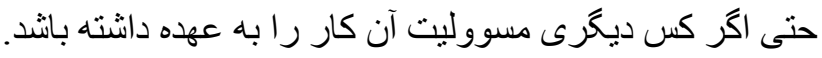

